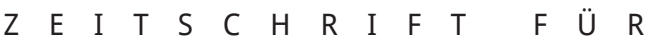

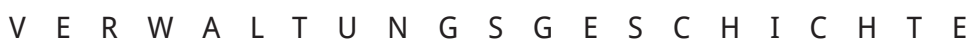

B A N D $3, \quad 20018$

S E I T E $80-95$

D O I : $10.2478 / \mathrm{ADH}$ I- $2018-0036$

\title{
Decency and Respect. New Perspectives on Emotional Bonds between State and Citizens
}

\author{
PETER BECKER ${ }^{1}$
}

Earning the confidence and trust of the people was the main objective of the Habsburg state's communication policy in the 1850s. An expanding state authority, reaching for the first time into the municipalities and villages of the entire realm, needed to assert its authority vis-à-vis its subjects. Active, communicative and integrative behaviour by state officials was expected to compensate for the closing of the parliament and the restriction of political rights after the revolution. ${ }^{2}$ Mobilising people for the state emotionally was a difficult task, even without the reversal of liberal political gains after the revolution. The state was - as contemporary observers emphasised - not a suitable object of emotional desire. In 1870, the German writer and politician Constantin Frantz found the state to be too much of a "colorless entity" for people to become emotionally attached to it. He followed the reasoning of Lessing, who had made the same point much earlier. For this reason, they preferred the nation over the state as a reference point for emotional attachment. ${ }^{3}$ The multinational state of the Habsburg monarchy could not pursue this strategy, however, and the government and emperor were forced to look for alternatives - which they found in the monarch himself along with the royal family, who were fashioned as reference points for emotional and patriotic attachment to the regime. The royal wedding of 1854 was carefully exploited to this end. ${ }^{4}$

Complementarily to the marketing of the royal family, the minister of the interior Alexander Bach urged his senior officials to secure trust in the state by establishing an emotional bond between the administration and its subjects. ${ }^{5}$ Bach shifted the emotion management of the subjects from a "ritual apparatus « triggering their emotional capacities ${ }^{6}$ towards an interactive model in which social factors, and thus also institutional ones, played a crucial role. His focus on the behaviour of public officials in encounters with the population can be read as an attempt to "actively manage inner feelings « on both sides of the interaction between state officials and citizens. Following the reasoning of Arlie Hochschild, I will argue that this "emotion work" was aimed not just at creating acceptable appearances ${ }^{7}$ but rather at »evoking or shaping, as well as suppressing, feelings $«{ }^{8}$

The task was hampered by the expansion of the state and its bureaucratisation. Increasing numbers of employees in the public service ${ }^{9}$ and the difficult social standing at the lower echelons of the organisation resulted in the presence of office holders whose claim to respect was based exclusively on their position in the public administration, as they lacked social background, 
family ties, economic means and education. To complicate this relationship between state officials and citizens even further, contemporary commentators did not view the bureaucratisation of the state that was generating all these jobs with unadulterated enthusiasm. They regularly pointed out the dysfunctionality of rationalisation, specialisation and expansion, and identified dispassionate, disinterested and cold public officials not as an asset but as a burden of the modern state, which they therefore distrusted. ${ }^{10}$

The 1850s were witness to several forms of emotion management: the masses organised after an attempt at the emperor's life by a knife-wielding Hungarian craftsman, a splendid royal wedding, the circulation of Alexander Bach's pastoral letter to his senior public servants, the marketing of a government loan ${ }^{11}$ and the introduction of a normative innovation, namely, the prohibition of writing to the authorities in a defamatory manner. All of these measures related to the generation, exploitation, control and containment of emotions towards the state. The law against defamatory speech acts directed at the authorities formed the more specific normative basis of emotion work in the relationship between state and citizens. ${ }^{12}$ However, it is discussed only in small circles of experts in public law who are not concerned with its wider political implications. ${ }^{13}$ This is quite unfortunate, since the law provides fascinating insights into emotion work, which operated on a cognitive level and aimed both to evoke and suppress emotions. ${ }^{14}$

The law originated in the early 1850s and remains in force today, thereby providing an excellent starting point for an exploration into continuities and changes concerning "feeling rules" for encounters between subjects and the state. As we can no longer study the "gestures of emotion work" in these interactions directly, I will use the proceedings of the administrative court (Verwaltungsgerichtshof) as a point of access. These proceedings appear rather detached from the situational encounters on which they deliberate but nevertheless offer the advantage that the reasoning of the judges provides further reflections on "feeling rules", that is on the definition of defamatory speech acts and their prosecution.

However, this strategy also has one serious disadvantage. The first case of this kind was discussed by the administrative court in 1927, two years after the legal norm was included in the codification of administrative procedures in $1925{ }^{15}$ Insults against the state were by no means nonexistent before; they were simply treated within a different legal framework - as can be deduced from the files of the emperor's chancellery, where such cases surfaced as soon as the defendants decided to file a pardon request. I address the reasons for this different legal framing in the first part of this essay while discussing the origins of the law against defamatory writing and its relation to the political and institutional culture of the 1850s. In the second part, a close reading of various defamatory speech acts and the reasoning of the judges at the administrative court provide insights into the strategies for drawing a line between criticism and defamation, as well as into the threats associated with emotional and emotionalising submissions to authorities.

\section{State and Citizens: Failed Attempts to Establish Shared Emotional Situations}

The 1850s were a watershed in the development of a modern state in Austria. With strong support of its military and Russian allies, the dynasty was able to emerge victorious from the revolution of $1848 / 49$. The new, neoabsolutist regime was eager to build a strong, centralised state, extending its reach for the first time into even the smallest boroughs and villages of the monarchy. ${ }^{16}$ This bestowed administrative authority onto an entirely new group of people - elected municipal officials who acted within the so-called übertragener Wirkungskreis, i.e. the field of competences in which the state used them to operate as unpaid public officials within their communities. ${ }^{17}$ From the perspective of a bureaucratic logic based on distance and objectivity, the hybrid position of these municipal functionaries was problematic. They were simultaneously neighbours, elected functionaries and unpaid public servants. To secure their authority in the latter function, an imperial decree was issued on 11 May $1851 .{ }^{18}$ In its preamble, this decree detailed its two closely related objectives: to secure the authority of state officials - including the hybrid type of elected municipal representatives 
- for the performance of their official duties and to guarantee the swift and precise execution of their orders. The decree regulated the enforcement of rules and prohibitions in general and proper behaviour in public in particular, the summons to court hearings and, finally, the ensuring of decent and polite behaviour of and towards the representatives of the state in their public functions:

\section{Just like state officials are obliged, under strict responsibility, to behave decently in their official dealings with everyone, they are equally entitled to be met with decency and respect by everybody when acting in their official duties. ${ }^{19}$}

Emperor Francis Joseph I was keen to reorganise the state in a more centralised manner. After the parliament had been closed down, he reigned with the support of both an advisory body and his ministers, some of whom had a strong liberal past. The decree of 1851, reissued in 1854 as an imperial decree in a slightly extended version and passed by the ministerial conference without critical comments, ${ }^{20}$ reflected the way in which the neo-absolutist state was conceived by the monarch and his government: as a moral authority that had been and still was endangered by subversive political forces and politically misled subjects. Both public servants and their subjects needed to be disciplined to assert the legitimacy of the state and win the loyalty of the people. This forced all parties to exhibit increasingly normalised behaviour when interacting with each other face to face or even in writing. Despite the asymmetry between public officials and citizens, the government believed that decency and respect created shared emotional situations during the encounter between public service and subjects and between state and society. ${ }^{21}$

Decency (Anstand) was expected from both sides in this asymmetric relationship between state officials and citizens. The German term Anstand transports a broad semantic field, and the specific meaning as used in the decree in question only emerged in the $18^{\text {th }}$ century to describe appearance and (linguistic) performance, i.e. proper outward conduct. ${ }^{22}$ Acceptable behaviour by public officials was thus judged exclusively on the grounds of their performance without considering
Kant argued, could be feigned but even then had the potential to generate respect in other people independent of the social standing of the person in question..$^{23}$ This relates well to the second part of the asymmetric relation between state and subjects. Citizens were expected to show respect (Achtung) for the state and its representatives. Respect, as the Kantian philosopher Wilhelm Traugott Krug put it, is an emotion directed towards people. The contemporary Brockhaus encyclopaedia even characterised respect as one of the "highest and purest of rational emotions", as a "sentiment of complete and purely moral acceptance of the character of another person and their way of acting ${ }^{24}{ }^{24}$ This conforms to the stipulations of the law of 1851/54: The decency in the performance of the official was to generate not only decency in return but also respect by the citizens. Being the object of this emotion, public officials should have personal merits such as talents, knowledge and an ethical attitude ${ }^{25}$ - or at least perform their duties with Anstand. Using the conceptual tools provided by Arlie Hochschild, we can therefore differentiate between emotion work required from officials and subjects. Public officials could limit their efforts to "surface acting", while citizens had to add a form of "deep acting", i.e. the generation of a specific emotion, to the superficial performance of decency as well. ${ }^{26}$

It is quite obvious that public officials in the Habsburg monarchy did not always perform their duties with the stipulated decency. Their most notorious deviations were flagrant exploitations of power to discriminate against people of a different nationality and/or political orientation, brutal responses to political protest in public spaces and a rather lackadaisical attitude concerning their official duties. ${ }^{27}$ The public did not always display the desired degree of respect towards officials either. The social relation between state officials and citizens was therefore put to the test at many occasions and was emotionally charged in a rather different way than envisioned by the law.

The state and its apparatus could be insulted at any occasion where direct contact with citizens, in person or in writing, was established. For this reason, the law of 1851/54 specifically safeguarded mayors and tax collectors as functionaries who engaged with citizens on a regular basis. After the end of the neo- 
absolutist era, the return to parliamentary elections created another venue where state functionaries had to confront subjects in an emotionally laden situation: parliamentary elections. For example, let us consider the events in the Hungarian village of Kötegyán on 12 March 1869. When the commission appeared and some villagers found themselves not included in the electoral register, emotions ran high and the affected citizens defended their rights against an authority they accused of having consciously violated the law. At this point, the commission withdrew, and in the aftermath, two villagers - Alexander Borzás sr. and Alexander Borzás jr. - were taken into custody and tried for insulting and slandering the commission as a state authority (Behörde) in concurrence with incitement to violate the law. Father and son were sentenced to six and nine months in prison, respectively. They petitioned the Hungarian minister of justice for pardon, a request that he forwarded to the emperor with a positive recommendation. It was eventually granted. ${ }^{28}$

The two men had openly challenged the ruling of a public authority, not in writing but rather using the spoken word. Their case is nevertheless worth considering within the framework of my argument, as it reveals a pattern that will reappear until the end of the $20^{\text {th }}$ century. First, the case of the Borzáses supports Monique Scheer's statement that »emotions are indeed something we do, not just have« ${ }^{29}$ Second, subjects do emotions within a concrete social interaction. Doing emotions cannot be understood without considering the situation. This was also the viewpoint from which the defendants argued. They saw their right to participate in the upcoming election violated - a right that they defended with an emotionally charged action. The members of the commission, however, proposed a different reading. They ignored the interactional and situational character of doing emotion and instead saw their just and reasonable decisions challenged in an irrational manner by way of insults and slander brought forth out of the blue by mischievous subjects.

Public authorities were eager to disregard their own obligations concerning behaviour during interactions and their participation in shared emotional situations as established by the law of $1851 / 54$. This was facilitated by a certain disregard by the law in the prosecution of slanderous speech acts. During the time of the monarchy, slanderous statements were treated as criminal acts. ${ }^{30}$ Even the emperor, who finally granted the pardon in the case of Alexander Borzás sr. and Alexander Borzás jr., did not read this conflict within the framework of shared emotional situations in which both public authorities and subjects were implicated, albeit asymmetrically. $\mathrm{He}$ instead focussed on the social and political context of the slanderous speech acts - the low level of education of the two defendants and the widespread misconceptions (Ideenverwirrung) regarding correct interpretation of the voting law in Hungary. On this basis, he was able to pardon the two culprits as an act of mercy.

The legal fiction of shared emotional situations between public authorities and subjects was never translated into bureaucratic practice. When regulating emotions, public authorities focused on citizens as addressees of administrative acts. The law of 1851/54 still entertained a broad understanding of this regulation, as it required both positive emotions from the citizens and outlawed acts of doing emotions that would disturb administrative procedure. ${ }^{31}$ The integration of this norm into the AVG (Allgemeines Verwaltungsgesetz) of $1925^{32}$ formally ended the imagined shared emotional situation, as it now regulated only the negative emotions of citizens and their threatening potential for administrative acts. The legally protected interest of the state administration remained the same on the surface: the protection of its reputation. ${ }^{33}$ However, browsing through the decisions of the administrative court, one can easily identify a shift from the protection of the administration's status towards the safeguarding of its performance. The latter was considered threatened, as I will argue, by submissions serving as carriers of emotional contagion, which had the potential to infect bureaucrats and thus disturb the objective performance of their duties.

\section{Dangerous emotional contagion}

The law of 1925 formed the starting point for systematic application of the legal provision against beleidigende Schreibweise, i.e. slanderous writing. It was included in section six of the law on administrative procedure, where fines for violating order and for frivolous abuse of administrative procedures (Ordnungs- und 
Mutwillensstrafen) were stipulated. These fines were instruments for the regulation of emotions, aiming at the suppression of negative emotions in the oral or written interaction between citizens and public authorities. Banning emotional and/or irrational speech acts appeared to be necessary to ensure proper working of the state apparatus. ${ }^{34}$

The more frequent use of this norm by public authorities provided an opportunity for the administrative court to establish a more precise difference between what could be said and what was considered defamatory, and to clarify the rationale for punishing slanderous writing in its rulings. The main challenge for the court was to define the thin line between permissible criticism against officials, their performance and public administration in general on the one hand and defamatory remarks on the other hand. Citizens who were fined for insulting the public service often challenged such rulings by pointing out that they had presented their criticism of the public service with the best intentions and under the protective shield of the freedom of speech.

When citizens displayed a lack of respect for public administration in their submissions, their argumentation mirrored the intellectual critique of the relatively capacious intervention of the state in economy and society in the postwar years. Emotional responses by citizens to emotionalising speech acts of the authorities were - unlike under monarchical rule - permitted in public discourse but not in submissions to the authorities. ${ }^{35}$ Only in the latter case were they regarded as wilful attempts to put spokes in the wheels of the administrative machinery.

What statements did the administrative court consider defamatory? A 1991 ruling of the Supreme Court of Justice collected relevant speech acts, which can be loosely grouped into three categories:

- accusations of abuse of power and dictatorial methods

- accusations of unlawful behaviour, fraud and corruption

- $\quad$ mocking of public officials

When judges had to decide on incriminated statements, they were forced to draw a line between the sayable and the defamatory and between rightful criticism and dangerous emotional contagion. They used two strategies for this purpose. First, they focussed on the speech act itself: As long as they assessed its intersubjectivity<, i.e. the facticity of the statements, they operated within the boundaries of their legal competence. If they considered a statement to have raised points that could not be subjected to a rational and empirically based assessment, they qualified the submission as beleidigende Schreibweise if they considered the non-rational argumentation to have been phrased in improper terms. When reading through the rulings and reflections of the administrative court, it is obvious that the judges believed in their competence to establish a clear division between emotional expressions, rational engagement with the social and physical world and (ultimately) their legal assessment. This assumption has been unmasked as modernist wishful thinking by sociological and psychological research. ${ }^{36}$ The administrative court nevertheless required citizens to maintain a performative distance from anger and frustration induced by administrative procedures, to focus their critique on the case itself (within the parameters of defending their legally defined interests) and to present it with a minimal amount of decency. ${ }^{37}$ The members of the administrative court were and are highly specialised legal experts and thus socialised into legal hermeneutics. ${ }^{38}$ They were, however, no experts in linguistic and semantic issues. Otherwise, they might have been more sensitive to the highly complicated linguistic situations they were dealing with. Citizens responded to performative speech acts by an authority, which presented them with a highly consequential understanding of their performance and/or requests. Reacting to these bureaucratic speech acts, citizens presented their vision of the case and understanding of the performance of public authorities. Their speech acts were intended to have an impact on administrative procedures - at least to motivate the officials to reconsider the case. When their responses were considered defamatory in the sense of beleidigende Schreibweise, their speech acts were assigned a further dimension: They were defined as offensive acts against public authorities or against a single official.

The judges of the administrative court did not look at debates on libel cases. The reason for this negligence 
may be found in the different linguistic strategies used to assess defamation. In penal law cases, potentially defamatory statements were judged on the basis of their perlocutionary character, i.e. their effect on the person being addressed. In the field of public law, when defamation concerned the public service or one of its members, the assessment could rely on neither the perlocutionary nor the illocutionary act, i.e. the intention of the speaker or writer. Stressing the perlocutionary act would have meant a return to the monarchical regime of honour, which was slowly giving way to a democratisation of state and public administration - as called for by the social democrats in the First Republic and more thoroughly implemented under the Kreisky government in the Second Republic. ${ }^{39}$ After these reforms, state and public administration were no longer set apart from the citizens and protected by a shield of honour but instead defined as institutions providing services to their subjects. Relying on the illocutionary aspects of the speech act would have required a systematic investigation of the writer's intention. ${ }^{40}$ This was not even an option for the supreme court, which argued that "it is not a matter of the asserted motivation, but of the actual behavior «. ${ }^{41}$

Judges at the administrative court navigated murky linguistic waters. One of their strategies was built on the assumed ability to differentiate objectively between defamatory and neutral semantics of words. Defamation as act of communication was thus abstracted from the writer, which came at the price of reducing speech acts to their propositional character. ${ }^{42}$ On this basis, the administrative court established criteria for the assessment of defamatory writing in a ruling in 1997. When the judges were confronted with a young woman's objection to the sentence of the appeal court in Tyrol (Unabhängiger Verwaltungssenat), they presented a more precise definition of defamation:

\section{If one attempts to define more precisely the term 'defamation, expressions must be associated with it that are offensive, hurtful, degrading, debasing, belittling, humiliating, disparaging, abusive, mocking, gibing, or expose to ridicule, that voice the accusation of contemptuous, shameful, disgraceful, morally condemnable actions, in short that are assertions,}

\author{
which are not approachable with reasoning and for \\ which a proof of truth is not worth considering. ${ }^{43}$
}

Browsing the rulings of the administrative court, the reference to an objective meaning of incriminated terms is used both against and in favour of the appeal. In the case of the young woman, the administrative court supported her claim. Her suggestion that the appeals court in Tyrol may have not considered her detailed recollection of the events in question as a result of a misogynist attitude or a lack of experience in dealing with people of average intelligence was regarded to possess no defamatory character as it displayed none of the abovementioned characteristics. ${ }^{44}$

In its rulings, the administrative court referred to the understanding of an "ordinary reader" and thus followed a line of reasoning well established in the American legal tradition. ${ }^{45}$ Even "ordinary readers" are sensitive to the context in which utterances are made. Linguistic context was therefore clearly on the judges' minds when they called for consideration of a provocative or scornful tone in order to assess the objective meaning of incriminated phrases. ${ }^{46}$ Looking at the phrasing of the entire submission and not just that of the incriminated parts was already common practice in the 1930s, as a ruling of the federal court (Bundesgerichtshof)-the successor of the administrative court in the Austrofascist State - suggests:

\section{Now, however, when examining whether a particular passage of a submission can be subsumed under $\$ 34$ $A V G$, the remaining content of the submission must be considered as well, because the meaning of words, if they are taken out of context, can thereby change. ${ }^{47}$}

In this case, this strategy was used to search for a general defamatory tone in a submission. The submission in question was a personal letter sent by an attorney to the Federal Chancellor of the Ständestaat that requested a secret investigation, as the sender saw no other way "to confront the unlawful actions of the security director of Styria «. ${ }^{48}$ In accordance with the law, the chancellery considered the letter an official submission and imposed a penalty for defamatory writing due to the insinuation that one of the top officials of the fascist state had abused his power. The judges of the federal 
court, while not being politically in opposition to the fascist state, ${ }^{49}$ decided otherwise. They considered the wording to be "a rationally presented summary assessment of those incidents in which the complainant believed to recognize an administrative performance of the security director that deviated from the law «. ${ }^{50}$ The judges mentioned some rather pointed expressions such as the reference to a regime of the security director but did not consider them sufficient proof for a lack of decency. ${ }^{51}$

The second strategy of the administrative court examined the negative effects of a specific speech act on administrative procedures. This brought the emotional side of the communication between citizens and public servants into the fore in both its perlocutionary and illocutionary aspects. Public administration built its self-image on the bureaucratic logic of its procedures, meaning rule-based assessment of facts and decisionmaking, and public servants figured as highly disciplined office holders whose subjectivity was not to affect these procedures. The successful performance of the public service, conceived in this ideal-typical notion by Max Weber, ${ }^{52}$ appeared to be compromised by defamatory speech acts directed against offices and officials. From this perspective, bureaucrats lost the ability to act rationally since they appeared so upset by the accusations.

A ruling from 1995 makes this point explicit. It states that an additional criterion for beleidigende Schreibweise was that it compromised the climate for negotiations (Verhandlungsklima) between citizen and office:

\section{being burdened by unreasonable expressions, inappropriate comparisons, allusions etc. in such a way that a rational, objective confrontation with the assertions is made difficult, if not impossible. ${ }^{53}$}

In resolving the appeal by a Viennese citizen who had insulted the Vienna magistrate with the wording vertrottelte Magistrate, i.e. half-witted magistrates, the administrative court dismissed his claim that his phrasing had simply aired his displeasure, instead deeming it to "poison the atmosphere of the administrative procedure.$^{54}$
This reasoning expresses the fear of a dangerous emotional contagion resulting from shared emotional situations between subjects and officials. It considers emotional outbursts and emotionalising submissions to pose a problem for bureaucrats, since it places them at risk of responding emotionally themselves to the citizen's defamatory speech act. The subjectivity and emotionality of public servants was systematically excluded from the basic conceptualisation of administrative procedures..$^{55}$ Therefore, any non-rational modality of acting was to be considered a deviance, the reason for which was located either in the wrongdoing of clients as external actors or in disciplinary problems of individual officials. ${ }^{56}$ The only remedy imaginable to the public authorities and the administrative court was the suppression of emotional and emotionalising speech acts.

The Viennese citizen who had used the phrase "halfwitted magistrates" defended his speech act with the right to free expression as guaranteed by the Human Rights Convention (HRC), which was ratified in Austria in 1958 and upgraded to the level of constitutional principle (Verfassungsrang) in 1964. Indeed, Article 10 of the HRC guarantees every person "the right to freedom of expression. This right shall include freedom to hold opinions «, as the HRC states. ${ }^{57}$ Was the Viennese citizen's speech act covered by the stipulations of the HRC? The judges of the administrative court decided it was not, pointing out that freedom of expression was not limitless but restricted by "duties and responsibilities" and thus "subject to such formalities, conditions, restrictions or penalties as are prescribed by law «..$^{58}$

Decisions on constitutional principles fell into the competence of the supreme court. It was the alternative and less often selected path for appeals against fines for defamatory writing. The sticking point of an appeal to the supreme court was the right to free expression. Its judges took a noticeably critical stance on the ruling of the administrative court by arguing that they were not always in line with the HRC. ${ }^{59}$ This introduced a new perspective on the assessment of defamatory writing, mainly from a perlocutionary perspective. The public service as addressee had to be very precise about its reasons for interpreting a speech act as a disturbance of administrative order. The position of citizens was strengthened without giving them a wild card for 
insulting public officials and making defamatory statements in submissions to the public service.

\section{Situation 1: facing the abuse of state power}

Frustrations about speech acts by state authorities were translated into an emotional assessment of the political order during the First Republic and more frequently during the Second Republic. When citizens engaged in doing emotion in their complaints, they more or less skilfully used references to contemporary public debates about the state and public administration. Their written complaints can be read as an emotional practice that aired their own displeasure and aimed to solicit negative emotional reactions from the members of the public service. ${ }^{60}$ The widespread concern with an expanding reach of the state, related to the threatening socialist revolution or the high level of state activity in the verwaltete Welt (Horkheimer/ Adorno) of the postwar years, facilitated a critical evaluation of the political system from emotionalised citizens. ${ }^{61}$ The language they used and the authorities' response depended on the specific political situation, on political debates and their semantics in the media and on generally accepted expectations in the state and administration. In the postwar years, defamatory speech acts by citizens usually compared the Austrian State to the Nazi past or to a fascist or communist regime. In the last years of the First Republic, rising political tensions provoked by fiscal demands to contain the effects of the economic crisis resulted in a call for authoritarian rule that openly displayed disrespect for democratic institutions.

Let me present an example from Tyrol to illustrate the challenge to republican rule in the late 1920s. In 1929, a property owner protested the increase in local taxes with a statement in which he callously challenged the existing political system and threatened its representatives with imminent constitutional and political change. His call for an authoritarian turn was coupled with a warning of the coming persecution of representatives of the existing regime - a speech act that expressed, from his viewpoint, a widely held popular discontent with the existing political order:

\begin{abstract}
The members of the municipal council should not have pleased the government representatives by taking such a threat seriously. They must remember that we are not yet in Russia, but are on the way, through modern constitutional amendments and through the introduction of political representations through estates, to revise the power of Parliament, of the provincial government and of the municipalities in a timely manner. This will hopefully also redefine the legal regulation of responsibility [...] We draw the attention of the provincial government in Tyrol particularly to the fact that its reputation is at stake if it is unwilling or unable to fulfill its obligations and duty.... because there is a fresh wind now blowing in Austria and the responsibility must and will be systemized. ${ }^{62}$
\end{abstract}

While the democratic underpinning of the state and its institutions was the target of this submission near the end of the First Republic and on the eve of the Austrofascist regime, discontent with the political system in the Second Republic blamed the state and public administration for its non-democratic performance. Defamatory speech acts after the Second World War were situated within a broad intellectual critique ranging from Horkheimer and Adorno to the American economist John Kenneth Galbraith, who identified the concentration of power in the bureaucratic structures of state and industry as a highly problematic feature of the New Industrial State. ${ }^{63}$ Administrative reform projects in the 1950s and 1960s did not respond to this fundamental critique, instead focussed on procedural questions. Concerns of citizens were taken up only with regard to the performance of the public service. The populace had to wait until the 1970s to witness a radical shift in perspective when Bruno Kreisky, head of the Austrian State and passionate reader of Galbraith, promised in his programmatic speech of 1975 to democratise the state and to "fundamentally change the relation of citizens to the state «. ${ }^{64}$

The expansion of the state along with the increasing complexity of the administration and its impact on the daily life of its subjects resulted in a "sense of impotence«, as Kreisky would remark with remorse in a later government policy statement. ${ }^{65}$ This statement must be interpreted within the context of the political 
culture in Austria. Support for authoritarian political solutions diminished only slowly, and the idea of a strong state still exerted great fascination. The appeasement policy practiced between the two main political parties led to a systematic division of the social, economic, and political spheres into two camps. Austrian subjects were thus integrated into lifeworlds and working situations that were basically structured by party affiliation. This segmentation (Versäulung) further exacerbated the feeling of impotence by limiting agency and choice.

Since the 1960s, citizens increasingly blamed the public service for not conforming to the standards of a democratic state. Their speech acts were provocative, as the writers were very much aware of the negatively charged political past, and reached from mere suggestions (for example, by addressing a submission to the district police commissioner for Donaustadt, Dr. Adolf Hitlerplatz ${ }^{66}$ ) through references to an undemocratic authoritarian self-understanding of the public service ("in continuation, conscious of tradition, of the practices of suppression and covering up of Habsburg, Dollfußs and Hitler fascism $\aleph^{67}$ ) all the way to open comparisons to bureaucratic rule in non-democratic systems (»of presumptuousness and prepotency customary only in a police state $«) .{ }^{68}$

The authorities reacted to these provocations very sensitively and were frequently supported by the administrative court. When a Tyrolean was punished for violating mushroom preservation laws, he made a comparison to National Socialism in his appeal: "These fines are reminiscent of the NS-Regime «. ${ }^{69}$ The result was a penalty for defamatory writing. The administrative court considered the man's punishment justifiable even though he had merely used concepts and expressions circulating within political and media debates. Claiming an analogy between the performance of the provincial government of Tyrol and the NS-state was permissible in a public or semi-public setting but unacceptable in a written submission. The administrative court reasoned in its verdict:

The accusation that such fines are reminiscent of the Nazi past was not only capable of belittling the authority's reputation, but also constituted one of

\author{
against an authority in a democratic constitutional \\ state.
}

Public officials would have been emotionalised by this belittling of the state and thus lost their ability to act rationally.

The referential space for comparisons to nondemocratic systems was not limited to historical examples. The rivalry between political systems during the Cold War, a central topic in the media, made knowledge about the abuse of citizens' rights by the states on the other side of the Iron Curtain widely accessible. When airing their discontent with the Austrian state, citizens chose neither the state socialism of the German Democratic Republic nor the 'goulash communism ‘ of Hungary as points of comparison but rather Ceaușescu's Romania and Hoxha's Albania. The authorities' response was invariably the same: administrative penalties for defamatory writing. The attitudes of the administrative court or the supreme court on these comparisons diverged, however, depending on the political and institutional contexts.

\section{Cold expropriations exist nowhere in Europe today, not even the last communist country Albania dares such a robbery of land. Only in the most repressive province in Austria, namely in Tyrol, is it usual practice that a municipality, assisted by the provincial agricultural offices, can take over land belonging to an individual and fix the price for this property itself without asking the expropriated farmers what price they ask for their land. ${ }^{70}$}

It was with these words that a Tyrolean farmer established an analogy between the practice of Kommassierungen, i.e. land merger proceedings, at the communal level and the widely known disregard of socialist states for private property. In his appeal against the fine for defamatory writing, he justified his phrasing with the broad public criticism of the Kommassierung procedure, which was even condemned by the European Court of Human Rights. The provincial government of Tyrol and its agricultural authority had acted in an undemocratic manner, as he claimed, because they enforced a legally based programme against the will and without involvement of those affected. From the 
point of view of the administrative court, however, the agricultural authorities had operated within the boundaries of the law. Based on the assumption that the lack of communication between the agricultural agency in charge of the merger program and the farmers did not contradict the program's correct application, the judges considered his assertions unacceptable as they posed in a democratic constitutional state an absolute insult to the authority «. ${ }^{71}$

Assessing the defamatory character of a statement requires an act of interpretation or in the words of one administrative court judge: "Judging writing to be defamatory constitutes the solution of a legal question « ${ }^{72}$ The »objectively defamatory character « of a statement must be weighed against the obligation of the public service and its members "to accept utterances of criticism, resentment and accusation without exaggerated sensitivity in a democratic society ${ }^{{ }^{73}}{ }^{3}$ The administrative court held that the Tyrolean farmer had exceeded the limits of permissible criticism and expression of discontent. Tyrol is not as undemocratic as communist Albania! In a similar case, however, the supreme court decided differently, agreeing that the Carinthia of the 90s could be compared to Romania under the rule of Ceaușescu.

In an appeal filed against the decision of a municipality in a building law case (Baurechtsangelegenheit), a lawyer made the following statement: "In political systems conforming to the model of Ceaușescu, appeal authorities have to act according to their mandate as a mere confirmation machinery «. ${ }^{74} \mathrm{He}$ criticised in particular that the deputy mayor was both the building permit applicant and the chairman of the appeal authority. Unlike the disciplinary senate of the Bar Association, the supreme court considered this statement legitimate as it was covered by the right to freedom of expression and the lawyer's duty to use all means to further the case of his client "which do not conflict with his mandate, conscience and laws«. His statement clearly pointed to a weakness in the procedures: "the combination of sovereign and private powers is understandable in a regime such as that of Ceaussescu, but not in a constitutional state such as the Republic of Austria «. ${ }^{75}$

\section{Situation 2: facing the public servant}

Public officials could be emotionalised most easily by the classic criticisms voiced against bureaucracy: dishonest attitudes, incompetent performance and lack of work ethics - if we disregard the few psychotic and scatological expressions. The (predominantly male) writers used the same `crude` and `expressive language to communicate with authorities that was and still is widely used in public comments on public service. ${ }^{76}$ By changing the communicative framework from drinking buddies to written submissions, however, that register became inappropriate.

The authorities reacted particularly touchily to phrases that ascribed an "abject disposition « to officials. A car driver who had been punished for drunk driving, for example, asserted that "police officials who were, of course, on duty to supervise the sso-called parties get drunk there. Then they mount their patrol car and make sofficialı observations". The administrative court considered this statement to imply an »abject disposition" of police executives and that it was therefore unacceptable. The concept of disposition enabled the administrative court to establish a connection between the administrative culture and the performance of individual civil servants. The organisation of work flows and the work ethic in the public service were explicitly addressed by some citizens. They used widely held stereotypes to be found in contemporary debates such as "the notion of the ssluggard in the public service $\ll .^{77}$
because if vastly overpaid but inactive and lazy Austrian officials continue to torment, discriminate and harass the citizens, would that also be a good alternative for those, in my opinion, strange deniers of engineering titles and bulliers of graduates from universities of applied science in Burgenland to save themselves from the envy and resentment of the unpropertied (unfortunately do not even have a school leaving examination themselves, no patents, do not speak a single foreign language, but are expected to assess multilingual high school and university graduates)?78 
This grammatically incorrect submission is the outcry of a graduate from a university of applied science who had applied for permission to use the title of Diplom-Ingenieur (degreed engineer). The decision on his application was delayed for procedural reasons; there were documents missing, at least from the authorities' point of view. From the graduate's perspective, the problem lay in the malfunctioning of the state apparatus. Unlike in the sreal world, where money was paid for good performance, he claimed that officials received high salaries for inactivity and laziness. When they became active, it was to the detriment of the citizens, who were tortured and harassed. The writer identified the reason for this destructive behaviour in an envy complex by the officials directed against the talented and successful.

These reflections addressed the requirements for civil servants and was thus a topic that has accompanied critical discussions on public administration since the beginning of the $19^{\text {th }}$ century. Freiherr vom Stein identified the social and economic distance between citizens and civil servants as a central problem: He complained that officials were merely »interest-less without property" and therefore not sufficiently integrated into a liberal society considered to be composed of propertied men. ${ }^{79}$ In the 1980s and 1990s, the integration of the public service into the society was to be achieved through a commitment to a common work ethic and a high level of competence. The equality of property owners was to be replaced by the equality of competence and performance.

Lack of competence of individual officials is a recurrent topic in the submissions containing defamatory statements. The accusation could be made subtly, e.g. by pointing out that "the signature of the official who signed the decree is very similar to that of an illiterate $«^{80}$ or by way of a fundamental criticism of the state. The car driver who was punished for drunk driving, for example, asked whether the graduates from secondary schools working for the police or the gendarmerie "are able to cope with the power they are given « ${ }^{81}$ This mere philosophical question was not understood as such by the administrative court, and the administrative penalty for defamatory writing was therefore confirmed.
Recalling Erwin Ringel, the psychoanalytic commentator of Austrian contemporary history, this philosophical remark can be read differently. For Ringel, power is acceptable only if it "is coupled with a sense of responsibility in the best sense of the word «. ${ }^{82}$ No one should dare to claim authority based only on position but rather everyone should win respect and trust for their performance - a reasoning very much in line with $19^{\text {th }}$-century standards. ${ }^{83}$ The car driver linked his demand for civil servants to be moral and ethical persons to their education and thus to status issues. Moral integrity, intellectual competence and position within a social hierarchy were thus closely interwoven in his view. Ultimately, he positioned himself in a shared emotional situation with public officials: The same kind of »deep acting " (Arlie Hochschild) that was required of citizens should also be expected from them. ${ }^{84}$ The law of 1925 and the rulings of the administrative court openly opposed any attempts to understand the interaction between public officials and citizens in terms of a shared emotional situation.

\section{Conclusion}

The state aspires to generate positive emotions among its citizens, such as loyalty and the willingness to sacrifice property and blood for its persistence. The expansion of the state since the mid-19th century increased the financial burden on citizens and provided them with a rapidly increasing range of public goods and services. ${ }^{85}$ The result of this expansion was ambivalent, at least in regard to the citizens' emotional engagement with the state: The availability of public goods made the state more attractive, though not always more appealing in emotional terms. Increasing presence of the state within the life and work environments of citizens, however, was also coeval with frustration and the rise of other negative emotions.

Since the 1850s, negative emotions could be punished as contraventions when aired in submissions to the authorities. During monarchical rule, emotional criticism of the state was immediately linked to the emperor, which constituted a much more severe crime and was subject to criminal prosecution. The democratisation of state-society relations increased 
the possibilities for critical comments on state and administration. Nevertheless, citizens who presented their critical comments in an emotionally loaded submission to the public service were still fined for a contravention, i.e. for defamatory writing.

The stipulation in the AVG (Allgemeines Verwaltungsgesetz) of 1925 placed a heavy burden on the shoulders of the judges at the administrative court: They were charged with clearly demarcating acceptable criticism from defamatory speech acts. This led them into murky linguistic waters, navigating between illocutionary and perlocutionary aspects of a speech act while trying to focus on its referential character so as to protect public officials from emotional contagion. Instead of introducing emotional work routines into public service, citizens were and still are required to keep their emotions under control and react to (from their perspective) provocative acts by the administration and its officials in strictly rational terms. However, rational critique could not be unambiguously differentiated from defamatory writing.

Encounters between the state and its citizens often take place in emotionally charged situations. Subjects meet policemen on the street as active road users; they meet public officials when they file applications for services of various kinds or when they have to engage with tax authorities. ${ }^{86}$ These are the venues where the state was and is performed, and where interactions take place in shared emotional situations. The rulings on defamatory speech acts presented in this essay follow the logic of the law of 1925 and consider these shared emotional situations to be nothing but a dangerous pathway through which emotional contagion might reach the rationally operating bureaucratic world.

The administrative reform projects since the 1970s have aimed at thorough democratisation but equally at a redesign of office rooms where the public official interacts with subjects turned customers. Pleasantly designed offices, like the service offices of the district authorities and magistrates, are intended to promote a relaxed and objective discussion of requests, obscuring the power relations that still persist. Not all requests can be granted, however, and that fact in itself breeds discontent and a violated sense of justice, with all its possible repercussions in emotional and emotionalising surface of bureaucratic procedures does not extend to all jurisdictions. The authorities in charge of residence permits are less likely to be architecturally upgraded towards a service-oriented office space. Migrants, however, do not have sufficient means for access to the law and are positioned outside of any shared emotional situation with the civil servants in charge of their applications. 
1 The author wishes to thank Alison Frank, the editors and the reviewer of Administory as well as Arthur Schlegemilch and the participants of the conference Mensch und Staat, organised in 2014 at the Open University Hagen.

2 Vortrag des Ministers des Innern Alexander Bach, d.d. 18. 8. 1849, womit derselbe ein Exemplar jenes Rundschreibens zu Ah. Einsicht vorlegt, das er in Folge seiner Ernennung zum Minister des Innern an sämtliche Landes-Chefs ... mitgeteilt hatte, in: Friedrich Walter (ed.): Die Österreichische Zentralverwaltung. Abt. III, vol. 2, Vienna 1964, pp. 105-110, at pp. $106 \mathrm{f}$.

3 Cf. Reinhart Koselleck: "Staat und Souveränität, Part III«, in: Otto Brunner / Werner Conze / Reinhart Koselleck (eds.): Geschichtliche Grundbegriffe. Historisches Lexikon zur politisch-sozialen Sprache in Deutschland, vol. 6, Stuttgart 1990, pp. 25-64, at pp. 48-50.

4 Cf. Pieter Judson: The Habsburg Empire. A New History, Cambridge, Mass. 2016, pp. 233-238; Brigitte Hamann: Elisabeth. Kaiserin wider Willen, Vienna 1997, ch. 2. On the strategies for mobilizing the loyalty of citizens, cf. Laurence Cole / Daniel L. Unowsky: "Introduction«, in: Laurence Cole / Daniel L. Unowsky (eds.): The Limits of Loyalty. Imperial Symbolism, Popular Allegiances, and State Patriotism in the Late Habsburg Monarchy, New York 2007, pp. 1-10.

5 Cf. Waltraud Heindl: Josephinische Mandarine. Bürokratie und Beamte in Österreich, 1848-1914, Vienna 2013, pp. 54-57; Bach's reform attempts are echoed in later reform proposals: Fredrik Lindström: Empire and Identity. Biographies of the Austrian State Problem in the Late Habsburg Empire, West Lafayette 2008, pp. 46f. On trust as emotion, cf. Ute Frevert: „Vertrauen. Historische Annäherungen an eine Gefühlshaltung«, in: Claudia Benthien / Anne Fleig / Ingrid Kasten (eds.): Emotionalität. Zur Geschichte der Gefühle, Cologne 2000, pp. 178-197.

6 Cf. Arlie Russel Hochschild: „Emotion Work, Feeling Rules, and Social Structure«, in: American Journal of Sociology 85 (1979), pp. 551575 , at p. 554, for a critical review of this perspective of emotion management, which was strongly indebted to an organismic account of emotions. On the role of the media in triggering emotions, especially within the context of the nation state, cf. the works discussed by Birgit Aschmann: „Vom Nutzen und Nachteil der Emotionen in der Geschichte. Eine Einführung«, in: Birgit Oschmann (ed.): Gefühl und Kalkül. Der Einfluss von Emotionen auf die Politik des 19. und 20. Jahrhunderts, Stuttgart 2005, pp. 9-32, at pp. $29 f$.

7 Cf. Hochschild: »Emotion Work«, pp. 555-558, for a critique of Ervin Goffman's position, which focuses on appearance.

8 Hochschild: "Emotion Work«, p. 557 and p. 561.

9 Cf. Karl Megner: Beamte. Wirtschafts- und sozialgeschichtliche Aspekte des k.k. Beamtentums, Vienna 1985, pp. 343-348 on the social situation of public officials in the Habsburg monarchy after 1848, cf. Heindl: Josephinische Mandarine, pp. 131-148.

10 Cf. Jozef Olszewski: Bureaukratie, Würzburg 1904, p. 130; cf. also Peter Becker: »Bürokratie«, in: Docupedia-Zeitgeschichte, 30. 8. 2016 (DOI: http://dx.doi.org/10.14765/zzf.dok.2.695.v1).

11 Cf. Georg Christoph Berger Waldenegg: Mit vereinten Kräften! Zum Verhältnis von Herrschaftspraxis und Systemkonsolidierung im Neoabsolutismus am Beispiel der Nationalanleihe von 1854, Vienna 2002, ch. 2.

12 On the concept, cf. Hochschild: »Emotion Work«, pp. 551-575.

13 Cf. Georg Gaisbauer: „Die beleidigende Schreibweise im Verwaltungsverfahren im Spiegel der Rechtsprechung«, in: Österreichische Gemeinde-Zeitung 10 (1995), pp. 20-26.

14 Hochschild: »Emotion Work«, p. 561.

15 Cf. Peter Becker, "'... dem Bürger die Verfolgung seiner Anliegen erleichtern.く Zur Geschichte der Verwaltungsreform im Österreich des 20. Jahrhunderts«, in: Heinrich Berger et al. (eds.): Politische Gewalt und Machtausübung im 20. Jahrhundert. Zeitgeschichte, Zeitgeschehen und Kontroversen, Vienna 2011, pp. 113-138, at pp. 121-128; Gernot D. Hasiba: „Ein Meisterwerk österreichischer Gesetzgebungskunst. Die Genesis der Verwaltungsreformgesetze von 1925«, in: Geschichte und Gegenwart 6 (1987), pp. 163-186; Egbert Mannlicher: "Die österreichische Verwaltungsreform des Jahres 1925«, in: Zeitschrift für öffentliches Recht 5/3 (1926), pp. 1-38.

16 Cf. Judson: Habsburg Empire, ch. 5; Georg Seiderer: Österreichs Neugestaltung. Verfassungspolitik und Verwaltungsreform unter Alexander Bach 1848-1859, Vienna 2015, ch. 4. A comprehensive overview of the current debates concerning the neo-absolutist period can be found in Harm-Hinrich Brandt (ed.): Der österreichische Neoabsolutismus als Verfassungs- und Verwaltungsproblem, Vienna 2014.

17 On the new municipal law, cf. Milan Hlavačka: Zlatý věk české samosprávy 1862-1914 [The Golden Age of Czech SelfGovernment], Praha 2006; Jiří Klabouch: „Die Lokalverwaltung in Cisleithanien«, in: Adam Wandruszka / Peter Urbanitsch (eds.): Die Habsburgermonarchie 1848-1918. vol. II, Verwaltung und Rechtswesen, Vienna 1975, pp. 270-305; Jiří Klabouch: Die Gemeindeselbstverwaltung in Österreich 1848-1918, Vienna 1968.

18 Imperial decree of 11. 5. 1851 [...] wodurch eine Vorschrift für die Vollstreckung der Verfügungen und Erkenntnisse der politischen Obrigkeiten (d.i. der politischen Behörden und Gemeindevorsteher) erlassen wird, RGBI 1851/127.

19 Imperial decree of 11. 5. 1851, § 12; see also Imperial Decree of 20. 4. 1854, RGBI 1854/96, § 12, p. 348.

20 The ministerial conference had to be involved because the Reichsrat insisted on an imperial decree, and the conference therefore had to be heard. The ministry of the interior initially wanted to issue the norm as a ministerial decree, which was considered inadequate by Kübeck - a position for which he found support in the young Emperor: Communication of the president of the Reichsrat Karl Friedrich von Kübeck to the president of the ministerial conference Graf v. Bol-Schauenstein, MKK 1153/1854, 4. 4. 1854. On the discussion during the ministerial conference, cf. Waltraud Heindl: Die Protokolle des Österreichischen Ministerrates 1848-1867. III. Abteilung: Das Ministerium Buol-Schauenstein, vol. 3, Vienna 1984, pp. $200 f$.

21 I use this concept to pinpoint the situational, interactional character of communication that neither extended to an emotional community nor comprised an emotional space. The participants in these interactions shared emotional situations but could belong to different emotional communities defined by generation, class and education. On emotional community as a conceptual tool, cf. Barbara H. Rosenwein: "Problems and Methods in the History of Emotions«, in: Passions in Context 1 (2010), pp. 1-32, at pp. 10-24.

22 Jacob Grimm / Wilhelm Grimm: Deutsches Wörterbuch, vol. 1 (1854), Munich 1999, p. 474f.; cf. also Neuestes Conversations-Lexicon oder allgemeine deutsche Real-Encyclopädie für gebildete Stände, vol. 1, Vienna 1825, p. 316 . By looking at contemporary semantics, I follow the advice in Rosenwein: »Problems and Methods», p. 14f.

23 Kant 10, p. 151, cited from Grimm: Deutsches Wörterbuch, p. 475.

24 Brockhaus Conversations-Lexikon. Allgemeine deutsche RealEnzyklopädie, vol. 1, Leipzig ${ }^{13} 1882$, p. 111 . On respect as the most appropriate basis for social interaction within a multi-cultural world, cf. Aleida Assmann: "Höflichkeit und Respekt», in: Gisela Engel et al. (eds.): Konjunkturen der Höflichkeit in der Frühen Neuzeit, Frankfurt am Main 2009, pp. 173-189; Richard Sennett: Respect in a World of Inequality, New York 2011. 
25 Wilhelm Traugott Krug: Allgemeines Handwörterbuch der philosophischen Wissenschaften, Leipzig 1829, vol. 1, p. 37.

26 Cf. Hochschild: »Emotion Work«, p. 558 and p. 561.

27 Cf. Peter Becker: "Stolpersteine auf dem Weg zum kooperativen Imperium. Bürokratische Praxis, gesellschaftliche Erwartungen und sozialpolitische Strategien«, in: Jana Osterkamp (ed.), Kooperatives Imperium. Politische Zusammenarbeit in der späten Habsburgermonarchie, Göttingen 2018, p. 23-53, at p. 40-42; Heindl: Josephinische Mandarine, p. 101-105, at p. 113-120.

28 Cf. Vortrag des ungarischen Justizministers Horvát vom 18. 6. 1870, KK 2429/1870. I would like to thank Mr. Leitner for bringing this case to my attention.

29 Monique Scheer: "Are Emotions a Kind of Practice (And is That What Makes Them Have a History)? A Bourdieuan Approach to Understanding Emotion«, in: History and Theory 51 (2012), pp. 193220, at p. 194.

30 The law of 1851/54 did not find much resonance with administrators. In its fifth edition from 1895, Ernst Mayrhofer's handbook discussed the main ministerial decrees and supreme court decisions related to insults and defamatory speech acts in submissions to state offices. They were treated, however, as public defamation of the state to be prosecuted as a crime. What made these submissions a public statement? The state attorney used the nature of bureaucratic action for building his case: submissions to state authorities were read by more than one official and therefore considered public. Ernst Mayrhofer: Handbuch für den politischen Verwaltungsdienst, vol. 1, 5th ed., Vienna 1895, p. 360; cf. also the fine book by Philip Czech: Der Kaiser ist ein Lump und Spitzbube. Majestätsbeleidigung unter Kaiser Franz Joseph, Vienna 2010, p. 73-86. Czech analyses a series of cases from the Salzburg penal courts. Written and verbal attacks directed at the monarch or even at the state and its officials were considered major threats to the legitimacy of the political system and thus subjected to more harsh sentencing on the basis of the penal code: The legal norms relevant for these cases were the penal code of 1852, §§ 65, p. 278 and p. 312.

31 On the regulation of emotion in administrative procedures, cf. the introduction to this volume, section 3.

32 Bundesgesetz über das allgemeine Verwaltungsverfahren (AVG), BGBI 1925/274, § 34.

33 Cf. Gaisbauer: »Schreibweise«, p. 22.

$34 \mathrm{Cf}$. the remarks in the administrative court's ruling on the rationale for these fines on 30. 5. 1994: VwGH 92/10/0469, 30. 5. 1994 (RIS document id: JWR_1992100469_19940530X01); cf. also VwGH 89/14/044, 30. 11. 1993 (RIS document id: JWR_1989140144_19931130X01). In contrast to the laws of 1851 and 1854, the legislators foresaw specific regulations for legal representatives: they could not be fined, but their contravening performance had to be reported to their disciplinary authority: AVG $\S 34$, paras. 3 and 4 .

35 William Reddy: „Against Constructionism. The Historical Ethnography of Emotions«, in: Current Anthropology 38 (1997), pp. 327-351 emphasises the specific linguistic character of emotional expressions, as they have the "unique capacity to alter what they srefer s to or what they represent «". (p. 327) This is, however, not the focus of my reflections on defamatory speech acts in submissions to the authorities. I am concerned with emotionalised reasoning in submissions to the authorities where, for reasons of a modernist bureaucratic culture, emotions are permitted only as a kind of linguistic contraband.

36 Cf. Aschmann: »Emotionen«, pp. 17f.; Hilde Haider: »Emotionen als Steuerungselemente menschlichen Handelns«, in: Aschmann (ed.):
Gefühl und Kalkül, pp. 34-47, at p. 37; Daniela Saxer: »Mit Gefühl handeln. Ansätze der Emotionsgeschichte«, in: Traverse. Zeitschrift für Geschichte 14 (2007), pp. 15-29, at p. 16f.; Scheer: „Are Emotions a Kind of Practice«, p. 197 on the sembodied،, sgrounded and >distributed forms of cognition.

37 VwGH 94/17/0427, 28. 9. 1995 (RIS document id: JWR_1994170427_19950928X13); VwGH 94/10/0099, 4. 9. 1995 (RIS document id: JWR_1994100099_19950904X01); on the definition of "sachbeschränkt», cf. VwGH 84/03/1055, 11. 12. 1985 (RIS document id: JWR_1984030155_19851211X01).

38 Cf. Andreas Deutsch: "Historische Semantik aus Sicht der Rechtswissenschaft", in: Jahrbuch für Germanistische Sprachgeschichte 2 (2011), pp. 111-127, at p. 124.

39 Cf. Richard Novak: »Demokratisches Prinzip und Verfassungswandel«, in: Hedwig Kopetz / Joseph Marko / Klaus Poier (eds.): Soziokultureller Wandel im Verfassungsstaat: Phänomene politischer Transformation, Vienna 2004, pp. 117-130; on the simpeded reform under the Klaus government, cf. Oliver Rathkolb: Die paradoxe Republik. Österreich 1945 bis 2005, Vienna 2005, pp. 182-184.

40 VwGH 87/01/0048, 29. 4. 1987 (RIS document id: JWR_1987010048_19870429X02); cf. also VwGH 961, 19. 6. 1936, p. 195.

$41 \mathrm{VfGH}$ B2177/94, 26. 9. 1995 (RIS document id: JFT_10049074_94B02177_00).

42 John L. Austin: How to Do Things with Words. The William James Lectures delivered at Harvard University in 1955, Oxford 1962; John R. Searle: Speech Acts. An Essay in Language Philosophy, Cambridge 1969, pp. 136-146.

43 VwGH 97/17/0187, 27. 10. 1997 (RIS document id: JWR_1997170187_19971027X01).

44 VwGH 97/17/0187, 27. 10. 1997 (RIS document id: JWR_1997170187_19971027X01).

45 Roger W. Shuy: The Language of Defamation Cases, New York 2010 , ch. 2.

46 VwGH 17.723, 19. 10. 1933, p. 311; VwGH 16.143, 21. 5. 1930, p. 362 , where a scornful tone was found and used as evidence for defamatory writing.

47 Bundesgerichtshof 1063, 19. 12. 1936, pp. 318-321, at p. 321

48 Bundesgerichtshof 1063, p. 320

49 On the federal court, cf. Ilse Reiter-Zatloukal: »Der Bundesgerichtshof 1934-1938. Wendeexperte oder Verteidiger des Rechtsstaats?«, in: Clemens Jabloner et al. (eds.): Gedenkschrift für Robert Walter, Vienna 2013, pp. 657-678; on the legal system in the Austrofascist state, cf. Ilse Reiter-Zatloukal: „Die (Un)Abhängigkeit der Richter unter der austrofaschistischen und nationalsozialistischen Herrschaft«, in: Beiträge zur Rechtsgeschichte Österreichs 6 (2016), pp. 419-469, at pp. 424-437; on the political structures and state power in the Austrofascist state, cf. Emmerich Tálos: Das austrofaschistische Herrschaftssystem. Österreich 1933-1938, Vienna 2013, ch. 2 and 3.

50 Bundesgerichtshof 1063, p. 321

51 Bundesgerichtshof 1063, p. 321.

52 Cf. Hans-Ulrich Derlien / Doris Böhme / Markus Heindl: Bürokratietheorie. Einführung in eine Theorie der Verwaltung, Wiesbaden 2011, ch. 1 and 5; Stefan Breuer: »Max Webers Herrschaftssoziologie«, in: Zeitschrift für Soziologie 17 (1988), pp. 315-327.

53 VwGH 95/15/0125, 4. 10. 1995 (RIS document id JWR_1995150125_19951004X03).

54 VwGH 94/17/0427, 28. 9. 1995 (RIS document id: JWR_1994170427_19950928X01). 
55 The relevance of emotional work within a service-oriented public administration is not yet reflected in the reasoning of the administrative court. On this aspect, cf. Saxer: »Mit Gefühl handeln«, pp. $21 \mathrm{f}$.

56 Cf. the contribution by Therese Garstenauer in this volume. This assumption has been refuted by recent legal, sociological and ethnomethodological studies: Cf. Terry A. Maroney: „Emotional Regulation and Judicial Behavior", in: California Law Review 99 (2011), pp. 1485-1555, at pp. 1488f. and section III; Robert Garot, "Sprachspiele im Wohnungsamt», in: Peter Becker (ed.): Sprachvollzug im Amt. Kommunikation und Verwaltung im Europa des 19. und 20. Jahrhunderts, Bielefeld 2011, pp. 157-184

57 HRC Art. 10, para. 1.

58 Cf. also Gaisbauer: "Schreibweise«, p. $21 \mathrm{f}$.

$59 \mathrm{VfGH}$ B101/91, 12. 3. 1992 (RIS document id: JFT_10079688_91B00101_00).

60 On the concept of emotional practice, cf. Scheer: »Are Emotions a Kind of Practice«, pp. 209-212.

61 Cf. Aschmann: »Emotionen«, pp. 16f. on the emotional correlations of social structures, status and power.

62 VwGH 0764/29, 21. 5. 1930 (RIS document id: JWR_1929000764_19300521X01).

63 John Kenneth Galbraith: The New Industrial State. Boston 1985, pp. $406 f$.

64 Government declaration of 5. 11. 1975, in: Heinz Fischer et al. (eds.): Bruno Kreisky, Reden 1936-1980, vol. 1, Vienna 1981, p. 534.

65 Government declaration of 19. 6. 1979, in Fischer et al., Kreisky, Reden, vol. 1, pp. $795 f$.

66 VwGH 96/10/0033, 11. 5. 1998 (RIS document id: JWT_1996100033_19980511X00).

67 VfGH B101/91.

68 VwGH 87/11/0271, 25. 3. 1988 (RIS document id: JWR_1987110271_19880325X01).

69 VwGH 92/10/0469, 30. 5. 1994 (RIS document id: JWR_1992100469_19940530X01).

70 VwGH 91/07/0084, 16. 11. 1993 (RIS document id: JWR_1991070084_19931116X01).

71 VwGH 91/07/0084.

72 VwGH 96/10/0033, 11. 5. 1998 (RIS document id: JWR_1996100033_19980511X01).

73 Cf. VwGH 2008/09/0344, 15. 10. 2009 (RIS document id: JWR_2008090344_20091015X01) with further references; cf. also VwGH 2010/04/0133, 17. 4. 2012 (RIS document JWR_2010040133_20120417X01).

$74 \mathrm{VfGH}$ B13/92, 24. 6. 1992 (RIS document id: JFR_10079376_92B00013_01).

$75 \mathrm{VfGH} \mathrm{B13/92}$

76 Cf. Eva Kreisky: Bürokratie und Politik. Beiträge zur Verwaltungskultur in Österreich, Vienna 1986, p. 282.

77 Kreisky: Bürokratie und Politik, p. 578.

78 VwGH 2010/04/0133.

79 Heinrich Friedrich Karl Freiherr vom Stein: Briefe an den Freiherrn von Gagern 1813-1831, Stuttgart 1833, p. 91. Referring to this critique, Karl Heinzen characterised bureaucracy not just as »dull«, but as "mind-defunct« (geisttod): Karl Heinzen: Die Preußische Bürokratie. Darmstadt Lese 1845, p. 113; cf. also Bernd Wunder: Geschichte der Bürokratie in Deutschland, Frankfurt am Main 1986, p. 7.

80 VwGH 1188/80, 17. 9. 1980 (RIS document id: JWR_1980001188_19800917X01).

81 VwGH 98/02/0320, 20. 11. 1998 (RIS document id: JWR_1998020320_19981120X01).
82 Erwin Ringel: Zur Gesundung der österreichischen Seele, Vienna 1987, p. 86

83 Ringel: Seele, p. 82.

84 On citizens as subjects of administrative processes, cf. Balázs Brunczel: Disillusioning Modernity. Niklas Luhmann's Social and Political Theory, Frankfurt am Main 2010, p. 146; Walter Leiser: Das demokratische Reich. Reichsidee und Volksherrschaft in Geschichte und Recht, Berlin 2004, p. 514.

85 Cf. Peter Becker: „Der Staat - eine österreichische Geschichte?«, in: Mitteilungen des Instituts für Österreichische Geschichtsforschung 126 (2018), pp. 317-340.

86 Cf. Michael Lipsky: Street-Level Bureaucracy. Dilemmas of the Individual in Public Services, New York 1983, ch. 1. 


\section{Abstract}

The 1850s were witness to several forms of emotion management in the Habsburg monarchy, among them the prohibition of writing to the authorities in a defamatory manner. The so-called law against defamatory speech was one of many initiatives which contributed to the generation, exploitation, control and containment of emotions towards the state. As this law remains in force today, it provides an excellent starting point for an exploration into continuities and changes concerning sfeeling ruless for encounters between subjects and the state. My chapter explores these rules through the lens of the administrative court, where acceptable criticism had to be clearly demarcated from defamatory speech acts. Looking at these proceedings, it is evident that emotional work routines are missing in the public service. Therefore, citizens were and still are required to keep their emotions under control and react to provocative acts by public officials in strictly rational terms.

\section{About the Author}

Peter Becker teaches Austrian History at the University of Vienna. He pursues research on the history of the state, state building, and governance with a particular focus on the Habsburg Empire and its successor states. The cabinet chancellery of Emperor Francis Joseph and his pen-pushing activities are subject to a joint research project with Jana Osterkamp. To explore government activities and their critical reception, Peter Becker also studies proceedings from the supreme court and the administrative court as well as the documentation of administrative reform initiatives. His publications include Sprachvollzug im Amt, ed. in 2011. 